\title{
Perbedaan Peningkatan Kemampuan Komunikasi Matematis Siswa antara Model Eliciting Activities dan Discovery Learning
}

\author{
Riska Asmara ${ }^{1}$, Ekasatya Aldila Afriansyah ${ }^{2}$ \\ 1,2 Mathematics Education Departement, Institut Pendidikan Indonesia \\ e-mail: ekafrian@institutpendidikan.ac.id
}

\begin{abstract}
ABSTRAK. Rendahnya kemampuan komunikasi matematis siswa terhadap materi pembelajaran menjadikan siswa menganggap matematika merupakan pelajaran yang sulit. Aktivitas pembelajaran yang dilakukan hendaknya berpusat pada siswa, agar siswa memiliki kebebasan untuk memperdalam materi dengan pemahamannya sendiri. Dua model pembelajaran yang berpusat pada siswa dipilih sebagai solusi dalam mengatasi rendahnya kemampuan komunikasi matematis yaitu Model Eliciting Activities dan Discovery Learning. Tujuan penelitian ini adalah untuk mengetahui perbedaan peningkatan kemampuan komunikasi matematis siswa antara yang mendapatkan pembelajaran Model Eliciting Activities dengan yang mendapatkan pembelajaran Discovery Learning. Metode penelitian yang digunakan adalah kuasi eksperimen dengan populasi seluruh siswa kelas X SMA Negeri 15 Garut. Sampel dipilih secara acak sebanyak dua kelas yaitu kelas X MIPA 8 sebagai kelas eksperimen I yang berjumlah 32 orang siswa dan kelas X MIPA 7 sebagai kelas eksperimen II yang berjumlah 30 orang siswa. Kelas eksperimen I yaitu kelas yang mendapatkan pembelajaran Model Eliciting Activities dan kelas eksperimen II yaitu kelas yang mendapatkan pembelajaran Discovery Learning. Instrumen penelitian yang meliputi Instrumen tes kemampuan komunikasi matematis berupa soal uraian (Pretest dan Posttest) dan instrumen non tes berupa angket. Berdasarkan hasil analisis secara statistik diperoleh kesimpulan bahwa tidak terdapat perbedaan peningkatan kemampuan komunikasi matematis siswa antara yang mendapatkan pembelajaran Model Eliciting Activities dengan yang mendapatkan pembelajaran Discovery Learning. Peningkatan kemampuan komunikasi matematis pada kelas Model Eliciting Activities berada pada intepretasi sedang dan kelas Discovery Learning berada pada interpretasi rendah. Respon siswa terhadap pembelajaran Model Eliciting Activities dan pembelajaran Discovery Learning menunjukkan respon yang baik.
\end{abstract}

Keywords : Kemampuan komunikasi matematis, Model Eliciting Activities, Discovery Learning.

\section{PENDAHULUAN}

Pentingnya komunikasi dalam matematika sejalan dengan fungsi mata pelajaran matematika, seperti yang dikemukakan oleh Suherman, dkk. (2001) bahwa: Siswa diberi pengalaman menggunakan matematika sebagai alat untuk memahami atau menyampaikan suatu informasi misalnya melalui persamaan-persamaan, atau tabel-tabel dalam model-model matematika yang merupakan penyederhanaan dari soal-soal cerita atau soal-soal uraian matematika lainnya.

Dari pendapat tersebut bahwa fungsi matematika yang dipaparkan adalah dari aspek komunikasi. Kemampuan komunikasi matematis inilah yang akan menjadi alat untuk memahami atau menyampaikan informasi dengan bahasa matematika melalui persamaan, tabel, grafik ataupun model matematika

Kemampuan komunikasi matematis bukan hanya sebagai suatu kompetensi siswa yang harus diajarkan dan dipelajari, tetapi hendaknya diupayakan agar siswa mampu memecahkan suatu permasalahan matematik. Aspek komunikasi juga dapat melatih siswa untuk 
mengkomunikasikan gagasannya, baik secara tertulis maupun secara lisan. Namun, kenyataan di lapangan menunjukkan bahwa kemampuan komunikasi matematis siswa masih rendah. Adapun indikator kemampuan komunikasi matematis sebagian kecil menurut Sumarmo dan Hendriana (2014), sebagai berikut:

a. Melukiskan atau mempresentasikan benda nyata, gambar, dan diagram dalam bentuk ide dan atau simbol matematika.

b. Menjelaskan ide, situasi dan relasi matematik, secara lisan dan tulisan dengan menggunakan benda nyata, gambar, grafik dan ekspresi aljabar.

c. Menyatakan peristiwa sehari-hari dalam bahasa atau simbol matematika atau menyusun model matematika suatu peristiwa.

Selama ini pembelajaran yang dilakukan guru di kelas cenderung monoton yaitu banyak guru yang menggunakan pembelajaran dengan metode ceramah ataupun ekspositori. Pada metode ini pusat pembelajaran ada pada guru, guru menyampaikan materi pelajaran, siswa mendengar dan mencatat, kemudian apabila ada yang belum paham, siswa bertanya. Hal ini sejalan dengan pendapat Slettenhaar (Permana, 2010) yang menyatakan bahwa pada model pembelajaran sekarang ini, umumnya aktivitas siswa hanya mendengar dan menonton penjelasan guru, kemudian guru menyelesaikan sendiri dengan satu cara penyelesaian dan memberi soal latihan untuk diselesaikan sendiri oleh siswanya.

Kegiatan pembelajaran seperti ini kurang memberikan kesempatan kepada siswa untuk mengetahui pemahaman matematikanya sendiri. Hal ini dapat menyebabkan siswa untuk banyak mengahafal tanpa memahami materi pelajaran yang disampaikan oleh guru. Sangatlah penting seorang siswa memiliki kemampuan kreatif dalam memecahkan permasalahan matematis (Afriansyah, 2016). Dengan pembelajaran seperti ini, aktivitas siswa di dalam kelas kurang ditonjolkan sehingga mengakibatkan kemampuan komunikasi matematis siswa kurang berkembang.

Selain itu berdasarkan dari hasil pengamatan peneliti lakukan terhadap kondisi kelas pada saat PPL (Program Pengenalan Lapangan) di salah satu SMA Negeri di Kota Garut. Peneliti menemukan suatu masalah yaitu rendahnya kemampuan komunikasi matematis siswa, hal tersebut terlihat kebanyakan siswa kesulitan menginterpresentasikan soal uraian ke dalam model matematika dan banyak pula yang kebingungan dalam menafsirkan soal. Sementara itu, secara lisan siswa kurang berani untuk mengkomunikasikan gagasan-gagasan matematika melalui bahasa matematika yang tepat. Sejalan dengan penelitiannya Afriansyah (2017), bahwa siswa masih merasa malu dalam menyampaikan pendapat atau gagasannya.

Melihat kondisi pembelajaran matematika yang seperti ini, maka perlu adanya inisiatif dari guru dalam memilih pembelajaran yang tepat dalam melaksanakan pembelajaran matematika di kelas. Hal ini bertujuan agar pembelajaran matematika dapat lebih berkualitas dan terasa menyenangkan, sehingga peningkatkan kemampuan komunikasi matematik siswa dapat tercapai.

Sejalan dengan penelitian Miftah (2015) bahwa kemampuan komunikasi matematis siswa dapat meningkat dengan menggunakan menggunakan pembelajaran Model Eliciting Activities. Serta penelitian Heryani dan Lesmana (2017) bahwa kemampuan komunikasi matematis siswa dapat meningkat dengan menggunakan pembelajaran Discovery Learning. Jadi, pembelajaran yang dapat diterapkan untuk peningkatkan kemampuan komunikasi matematis siswa adalah dengan pembelajaran Model Eliciting Activities (MEAs) dan pembelajaran Discovery Learning.

Menurut Santi (2012) pembelajaran MEAs adalah pembelajaran untuk memahami, menjelaskan dan mengkomunikasikan konsep-konsep yang terkandung dalam suatu sajian masalah melalui proses pemodelan matematika. Dalam pembelajaran $M E A s$, kegiatan pembelajaran diawali dengan penyajian situasi masalah yang memunculkan aktivitas untuk menghasilkan model matematis yang digunakan dalam menyelesaikan masalah matematika. Jadi kemampuan komunikasi matematis inilah yang menjadi jalan untuk dapat menyelesaikan permasalahan matematika. 
Selain itu dalam pembelajaran MEAs siswa diharuskan berdiskusi dengan teman sekelompoknya kemudian mempresentasikan hasil diskusi tersebut kepada kelompok lain. Melalui cara seperti inilah siswa dapat mengembangkan kemampuan komunikasi matematisnya baik melalui representasi membentuk model, berdiskusi maupun presentasi hasil diskusi.

Beberapa penelitian relevan telah menerapkan model pembelajaran $M E A s$ dan terbukti dapat meningkatkan beberapa variabel kemampuan matematis, yaitu: kemampuan pemecahan masalah (Wijayanti, 2013); dan kemampuan komunikasi matematis (Wijayanti, 2013; Miftah, 2015).

Selain pembelajaran $M E A s$, peneliti menggunakan pembelajaran Discovery Learning. Russefendi (Nurdiansyah, 2008) mengatakan bahwa Discovery Learning adalah pembelajaran yang mengatur pengajaran sedemikian rupa sehingga anak memperoleh pengetahuan yang sebelumnya belum diketahuinya tanpa pemberitahuan langsung sebagian atau seluruhnya ditemukan sendiri.

Discovery Learning memberikan kesempatan yang leluasa kepada siswa untuk belajar melakukan aktivitas "bekerja" dalam mempelajari matematika, siswa diberi kesempatan mengembankan strategi belajarnya secara sendiri ataupun berinteraksi serta bernegosiasi dengan sesama siswa maupun dengan guru. Melalui kegiatan seperti itu, dimungkinkan siswa tidak merasa tertekan, tidak cemas, rasa percaya dirinya muncul dan termotivasi untuk belajar matematika. Seperti menurut Russeffendi (2006) "Pentingnya menemukan sesuatu oleh sendiri dapat menumbuhkan rasa percaya diri, meningkatkan motivasi dan dapat menumbuhkan sikap positif terhadap matematika".

Beberapa penelitian relevan telah menerapkan model pembelajaran Discovery Learning dan terbukti dapat meningkatkan beberapa variabel kemampuan matematis, yaitu: kemampuan analogi matematis (Rahman \& Maarif, 2014); kemampuan penalaran matematis (Burais, dkk, 2016; Arifudin, 2016); kemampuan koneksi dan komunikasi matematis (Heryani \& Lesmana, 2017).

Berdasarkan pemaparan di atas, mengenai uraian kemampuan komunikasi matematis, pembelajaran Model Eliciting Activities dan pembelajaran model Discovery Learning maka penulis tertarik melaksanakan penelitian dengan judul: Perbedaan Peningkatan Kemampuan Komunikasi Matematis antara Siswa yang Mendapatkan Pembelajaran Model Eliciting Activities dengan yang Mendapatkan Pembelajaran Discovery Learning.

Dari latar belakang di atas maka rumusan masalah dalam penelitian ini adalah sebagai berikut: 1) Bagaimana peningkatan kemampuan komunikasi matematis siswa yang mendapatkan pembelajaran Model Eliciting Activities? 2) Bagaimana peningkatan kemampuan komunikasi matematis siswa yang mendapatkan pembelajaran Discovery Learning? 3) Apakah terdapat perbedaan peningkatan kemampuan komunikasi matematis siswa antara yang mendapatkan pembelajaran Model Eliciting Activities dengan yang mendapatkan pembelajaran Discovery Learning?

\section{METODE PENELITIAN}

Jenis penelitian ini quasi eksperimen. Dengan mengambil dua kelas, kelas eksperimen I yang menggunakan pembelajaran $M E A s$ dan kelas eksperimen II yang menggunakan model pembelajaran Discovery Learning. Berdasarkan uraian, maka desain penelitian ini menurut Ruseffendi (2005) yang dinamakan Nonequivalen control group adalah sebagai berikut:

$\begin{array}{ccc}O & X_{1} & O \\ O & X_{2} & O\end{array}$

Keterangan:

$\mathrm{O}=$ Tes awal (pretest) dan tes akhir (posttest)

$\mathrm{X}_{1}=$ Pembelajaran menggunakan $M E A s$

$\mathrm{X}_{2}=$ Pembelajaran menggunakan Discovery Learning 
$\ldots . . .=$ Kedua kelompok tidak dipilih secara random

Populasi dalam penelitian ini adalah X SMA Negeri 15 Garut tahun ajaran 2017-2018. Adapun yang dijadikan sampel adalah siswa kelas X MIPA 8 sebagai eksperimen 1 dan X MIPA 7 sebagai eksperimen 2. Waktu penelitian terhitung dari tanggal 3 s.d 26 Januari 2018. Sedangkan tempat penelitian di SMA Negeri 15 Garut.

Dalam analisis data yang diperoleh dari hasil penelitian Pretest dan Posttest, langkah awal analisis data adalah menggunakan rumus Gain Ternormalisasi untuk memastikan adanya peningkatan hasil belajar atau tidak setelah dilakukan perlakuan pada kelas eksperimen 1 dan kelas eksperimen 2. Langkah kedua adalah menguji normalitas data hasil Gain Ternormalisasi Pengujian normalitas data ini diperlukan untuk menentukan jenis statistika apa yang nantinya akan dipakai untuk menguji hipotesis. Dalam penelitian ini digunakan uji Liliefors, uji homogenitas dua varians dan yang terakhir adalah uji perbedaan dengan uji t.

\section{HASIL DAN PEMBAHASAN Hasil Penelitian}

Penelitian dilaksanakan di SMA Negeri 15 Garut dari data hasil penelitian dengan memberikan perlakuan kepada dua kelas yaitu kelas X MIPA 8 sebagai kelompok yang mendapatkan pembelajaran Model Eliciting Activities disebut kelas eksperimen 1 yang berjumlah 32 siswa dan kelas X MIPA 7 sebagai kelompok yang mendapatkan pembelajaran Discovery Learning disebut kelas eksperimen 2 yang berjumlah 30 siswa. Kedua kelas tersebut diberikan tes awal (pretest) dan tes akhir (posttest), diperoleh hasil pada Tabel 1 sebagai berikut:

Tabel 1. Data Hasil Penelitian

\begin{tabular}{ccccc}
\hline \multirow{2}{*}{ Keterangan } & \multicolumn{2}{c}{$\begin{array}{c}\text { Model Eliciting } \\
\text { Activities }\end{array}$} & \multicolumn{2}{c}{ Discovery Learning } \\
\cline { 2 - 5 } & Pretest & Posttest & Pretest & Posttest \\
\hline Jumlah Siswa & 32 & 32 & 30 & 30 \\
\hline Skor Ideal & 16 & 16 & 16 & 16 \\
\hline Nilai Terbesar & 6 & 14 & 7 & 14 \\
\hline Nilai Terkecil & 0 & 3 & 0 & 3 \\
\hline Rata-rata & 3.47 & 8.16 & 4 & 7.3 \\
\hline Simpangan Baku & 1.46 & 3.26 & 2.17 & 3.22 \\
\hline
\end{tabular}

Dari hasil penelitian untuk data pretest, skor maksimum kelas $M E A s$ adalah 6 dan skor minimumnya 0 . Sedangkan rata-ratanya adalah 3,47 (21,67\%) dan simpangan bakunya 1,46. Skor maksimum kelas Discovery Learning adalah 7 dan skor minimumnya 0. Sedangkan rata-ratanya adalah $4(25 \%)$ dan simpangan bakunya 2,17. dan untuk data posttest, skor maksimum kelas $M E A s$ adalah 14 dan skor minimumnya 3. Sedangkan rata-ratanya adalah 8,16 (51\%\%) dan simpangan bakunya 3,26. skor maksimum kelas Discovery Learning adalah 14 dan skor minimumnya 0. Sedangkan rata-ratanya adalah 7,3 (45,62\%) dan simpangan bakunya 3,22.

Setelah mendapatkan data hasil penelitian melalui pretest dan posttest, kemudian dari data tersebut diolah sehingga menghasilkan data gain ternormalisasi. Dalam penelitian ini, peneliti ingin mengetahui peningkatan kemampuan setiap siswa di dalam pembelajaran dengan menggunakan perlakuan. Kemampuan yang di teliti adalah kemampuan komunikasi matematis siswa antara sebelum dan sesudah diberikan perlakuan didalam pembelajaran di kelas tersebut. Dari hasil pretest dan posttest yang diberikan kepada kedua kelas. Adapun hasil yang didapat disajikan pada tabel 2 sebagai berikut: 
Tabel 2. Data Hasil Interpretasi Peningkatan

\begin{tabular}{lllllll}
\hline \multicolumn{1}{c}{ Kelas } & $\begin{array}{c}\text { Jumlah } \\
\text { Siswa }\end{array}$ & $\begin{array}{c}\text { Nilai } \\
\text { Maks }\end{array}$ & $\begin{array}{c}\text { Nilai } \\
\text { Min }\end{array}$ & Rata-rata & $\begin{array}{c}\text { Simpangan } \\
\text { Baku }\end{array}$ & $\begin{array}{c}\text { Interpretasi } \\
\text { Peningkatan }\end{array}$ \\
\hline $\begin{array}{l}\text { Model Eliciting } \\
\text { Activities }\end{array}$ & 32 & 0,85 & 0 & 0,38 & 0,25 & Sedang \\
\hline $\begin{array}{l}\text { Discovery } \\
\text { Learning }\end{array}$ & 30 & 0,78 & 0 & 0,27 & 0,25 & Rendah \\
\hline
\end{tabular}

Dari data gain ternormalisasi yang diperoleh dari kelas MEAs dan model Discovery Learning yang bertujuan untuk mengetahui kualitas peningkatan kemampuan akhir siswa setelah diberikan perlakuan atau pembelajaran. Setelah data terkumpul, lalu peneliti melakukan perhitungan statistik maka diperoleh $t_{\text {hitung }}=0,2480$ dan $t_{\text {tabel }}=2,0003$. Karena $-t_{\text {tabel }}=-2,0003<t_{\text {hitung }}=0,2480<t_{\text {tabel }}$ $=2,0003$ ternyata berada pada daerah penerimaan Ho, maka dapat disimpulkan "Tidak terdapat perbedaan peningkatan yang signifikan antara kemampuan komunikasi matematis siswa yang mendapatkan pembelajaran Model Eliciting Activities dengan yang mendapatkan pembelajaran Discovery Learning."

\section{Pembahasan}

Kegiatan penelitian ini merupakan kegiatan pembelajaran yang dilaksanakan pada awal januari 2018 di SMA Negeri 15 Garut program MIPA kelas X, dengan materi Relasi dan Fungsi. Pebelajaran yang dilakukan pada penelitian ini bertujuan untuk mengetahui sejauh mana peningkatan kemampuan komunikasi matemtis siswa terhadap pembelajaran matematika. Pengambilan sampel dilakukan secara acak. Setelah berkoordinasi yang bersangkutan maka kelas yang dijadikan sampel penelitian adalah kelas X MIPA 8 sebagai kelas Model Eliciting Activities dan X MIPA 7 sebagai kelas Discovery Learning.

Kegiatan pembelajaran kedua kelas berlangsung dalam waktu yang sama yaitu selama 4 kali pertemuan. Kedua kelas, kegiatan pembelajaran kondusif, aktif dan para siswa bersemangat untuk mengikuti proses pembelajaran dengan menggunakan Model Eliciting Activities dan Discovery Learning, telihat pada gambar 1 dan gambar 2 sebagai berikut:

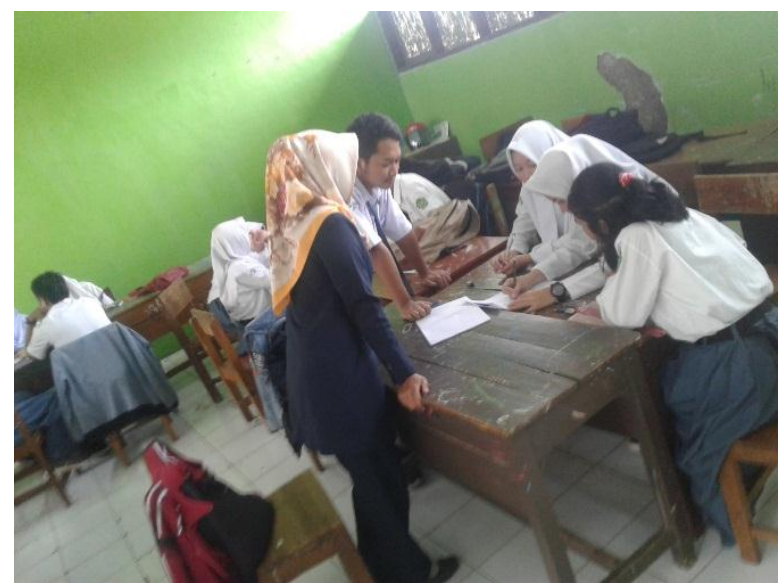

Gambar 1. Kegiatan pembelajaran Model Eliciting Activities 


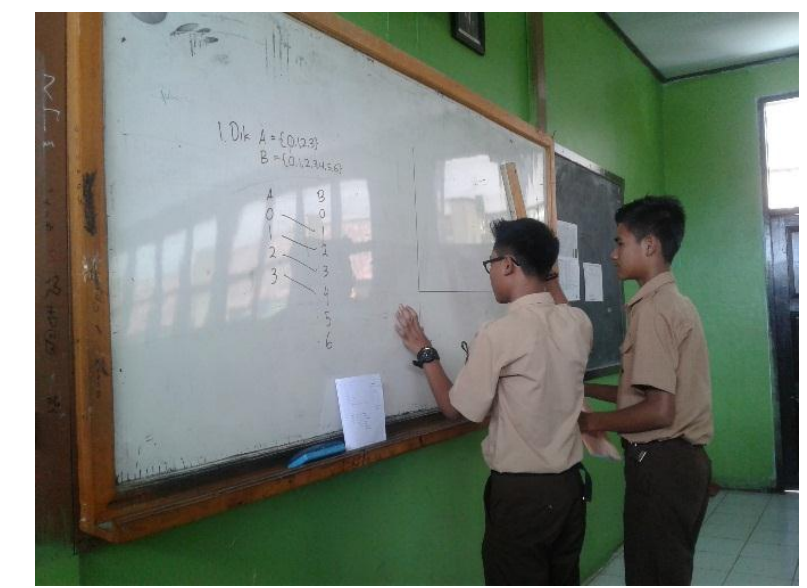

Gambar 2. Kegiatan pembelajaran Discovery Learning

Selama dilakukannya penelitian, peneliti menemukan beberapa kelebihan dan kekurangan dari kegiatan pembelajaran yang menggunakan Model Eliciting Activities. Kelebihan yang peneliti temukan dalam kegiatan pembelajaran selama menggunakan pembelajaran Model Eliciting Activities, yaitu:

a. Siswa mulai terbiasa belajar secara berkelompok dan mulai terbiasa menghargai perbedaan sikap dan karakter diantara teman sekelasnya.

b. Adanya diskusi kelompok yang membantu siswa untuk terlibat aktif dalam pembelajaran, terbiasa untuk menghargai perbedaan pendapat dan terbiasa untuk dapat memecahkan masalah bersama-sama sehingga membentuk pemahaman yang sama dalam kelompok.

c. Dengan menggunakan pembelajaran Model Eliciting Activities dalam kegiatan mempresentasikan hasil diskusi, siswa mulai terlatih untuk berani mengemukakan pendapatnya dan berani untuk bertanya terhadap hal-hal yang belum dipahami. Hal ini akan membantu perkembangan siswa dalam belajar.

Namun selain kelebihan yang dipaparkan di atas, terdapat beberapa kekurangan yang peneliti temukan dalam kegiatan pembelajaran selama menggunakan pembelajaran Model Eliciting Activities diantaranya:

a. Dengan adanya kelompok memberikan kesempatan kepada siswa untuk mengobrol dengan teman kelompoknya, hal ini terlihat saat pembelajaran dimana masih terdapat beberapa siswa yang asik mengobrol dengan teman kelompoknya membahas hal-hal diluar materi pembelajaran.

b. Saat diberikan permasalahan, siswa belum paham terhadap masalah yang diberikan, siswa mulai bertanya kepada guru sampai guru kewalahan menanggapi pertanyaan siswa. Hal ini menjadikan suasana kelas gaduh sehingga konsentrasi siswa berkurang.

c. Dengan waktu yang terbatas, membuat siswa tidak leluasa dalam menganalisis permasalahan yang disajikan.

Sama halnya dengan kelas Model Eliciting Activities selama dilakukannya penelitian peneliti menemukan beberapa kelebihan dan kekurangan dari kegiatan pembelajaran selama menggunakan pembelajaran Discovery Learning. Kelebihan yang peneliti temukan dalam kegiatan pembelajaran selama menggunakan model pembelajaran Discovery Learning, yaitu:

1. Siswa dapat belajar sesuai dengan kemampuan dan pemahamannya sendiri.

2. Siswa dengan kelompoknya aktif bekerja sama dalam menemukan penyelesaian masalah yang ada dalam lembar kerja kelompok.

3. Suasana belajar lebih menarik karena siswa terlibat aktif dalam pembelajaran, terutama saat memperesentasikan hasil diskusi. Adanya kegiatan tanya jawab antar kelompok untuk mengumpulkan informasi-informasi lain yang dapat memperdalam pemahamannya terhadap materi yang sedang dipelajari. 
Namun selain kelebihan yang dipaparkan di atas, terdapat beberapa kekurangan dalam kegiatan pembelajaran selama menggunakan pembelajaran Discovery Learning, diantaranya:

a. Saat diberikan permasalahan, siswa belum paham terhadap masalah yang diberikan, siswa mulai bertanya kepada guru sampai guru kewalahan menanggapi pertanyaan siswa. Hal ini menjadikan suasana kelas gaduh sehingga konsentrasi siswa berkurang.

b. Dengan waktu yang terbatas, membuat siswa tidak leluasa dalam menganalisis permasalahan yang disajikan.

Pembelajaran dengan menggunakan model pembelajaran Discovery membutuhkan rasa ingin tahu dan motivasi belajar yang tinggi dari masing-masing siswa. Jika tidak ada adanya rasa ingin tahu dan motivasi belajar yang tinggi dari masing-masing siswa maka pembelajaran tidak berjalan optimal. Terlihat dari kelompok-kelompok yang sudah dibentuk, ada beberapa kelompok yang tidak termotivasi dalam belajar sehingga disaat pembelajaran berlangsung kelompok tersebut hanya mengobrol dengan teman kelompoknya dan membuat kegaduhan di kelas.

Dari sintaks pembelajaran kedua model yang hampir sama maka hasil dari penelitian ini menunjukan tidak terdapat perbedaan peningkatan kemampuan komunikasi matematis siswa antara yang mendapatkan pembelajaran Model Eliciting Activities dengan yang mendapatkan pembelajaran Discovery Learning.

Pada dasarnya kelas eksperimen 1 dan kelas eksperimen 2 sama-sama mengalami sedikit peningkatan kemampuan komunikasi matematis yang berbeda, siswa di kelas eksperimen yang mendapatkan pembelajaran Model Elicitng Activities mengalami mengalami peningkatan yang lebih baik daripada siswa di kelas eksperimen 2 yang mendapatkan pembelajaran Discovery Learning. Hal ini dibuktikan dengan nilai rata-rata peningkatan yang diperoleh yaitu 0,38 untuk kelas eksperimen dengan kriteria sedang, dan 0,27 untuk kelas kontrol dengan kriteria rendah.

Dilihat dari hasil pencapaian kemampuan komunikasi matematis menunjukan bahwa pembelajaran kelas Model Eliciting Activties siswa yang tuntas mencapai KKM berjumlah 10 orang dengan persentase $31,25 \%$ dan siswa yang tidak tuntas mencapai KKM berjumlah 22 orang dengan persentase $68.75 \%$ dan pembelajaran kelas Discovery Learning siswa yang tuntas mencapai KKM berjumlah 5 orang dengan persentase $16,67 \%$ dan siswa yang tidak tuntas mencapai KKM berjumlah 25 orang dengan persentase $83,33 \%$. Maka kemampuan komunikasi matematis siswa baru mencapai nterval 5\% sampai 65\% dari jumlah skor seluruhnya.

Peneliti berpendapat bahwa ada beberapa faktor penyebab tidak terjadinya perbedaan, diantaranya sebagai berikut:

a. Kedua kelas eksperimen sama-sama diberikan lembar kerja kelompok. Pada kelas Model Eliciting Activities siswa mendapatkan lembar kerja kelompok yang didalamnya terdapat soal kehidupan sehari-hari siswa melakukan analisis terhadap soal tersebut kemudian membuat kesimpulan dari hasil anlisis bersama kelompoknya. Pada kelas Discovery Learning pun siswa mendapatkan lembar kerja kelompok, yang didalamnya terdapat persoalan yang harus dianlisis oleh siswa bersama kelompoknya untuk bisa membuat kesimpulan dari hasil anlisis kelompoknya. Kedua kelas eksperimen melakukan analisis dari permasalahan yang terdapat didalam LKS untuk dapat membuat kesimpulan. Dalam mengerjakan LKS, para siswa di kelas eksperimen dan kelas kontrol memiliki motivasi belajar yang tinggi sehingga dapat menyelesaikan LKS dengan baik.

b. Pada kelas Model Eliciting Activities siswa mempresentasikan hasil diskusinya dan kelompok lain menanggapi. Hal ini bertujuan untuk membantu siswa berani menyampaikan pendapatnya sendiri sesuai dengan apa yang siswa pahami dan dapat menambah informasi kepada siswa lain. Pada kelas Discovery Learning siswa mempresentasikan hasil diskusinya dan kelompok lain menanggapi hal ini bertujuan untuk menambah informasi sekaligus pengumpulan data untuk menguji kesimpulan yang sebelumnya sudah dibuat oleh masingmasing kelompok. Pada kegiatan mempresentasikan hasil diskusi para siswa di kelas eksperimen 1 dan Kelas eksperimen 2 dilatih untuk menyampaikan pendapat dari hasil diskusi dan pemahaman kelompoknya masing-masing. 
Secara keseluruhan selama empat kali pertemuan, baik kelas Model Eliciting Activities dan kelas Discovery Learning keduanya dapat mengikuti serangkaian proses pembelajaran dengan baik. Dari hasil perhitungan distribusi skor sikap siswa terhadap pembelajaran Model Eliciting Activities, diperoleh bahwa sikap siswa bersikap positif. Hal ini ditunjukan dengan total skor 2572,14 berada pada rentang $2500 \leq \mathrm{s}<3302$ dengan interpretasi baik. Disajikan pula data dalam bentuk presentase, setelah dilakukan perhitungan mengenai skala sikap setiap individu kelas Model Eliciting Activities sebagai berikut:

Tabel 3. Interpretasi Skala Sikap Setiap Individu MEAs

\begin{tabular}{cccc}
\hline Nomor & Interpretasi & $\begin{array}{c}\text { Banyak } \\
\text { Siswa }\end{array}$ & $\begin{array}{c}\text { Persentase } \\
\mathbf{( \% )}\end{array}$ \\
\hline 1 & Sangat Jelek & 1 & 3,12 \\
\hline 2 & Jelek & 9 & 28,12 \\
\hline 3 & Baik & 19 & 59,38 \\
\hline 4 & Sangat Baik & 3 & 9,38 \\
\hline Jumlah & & 32 & 100 \\
\hline
\end{tabular}

Jadi, dapat disimpulkan bahwa interpretasi skala sikap siswa tiap individu terhadap pembelajaran matematika dengan menggunakan model pembelajaran Model Eliciting Activities berinterpretasi baik.

Dari hasil perhitungan distribusi skor sikap siswa terhadap pembelajaran Discovery Learning, diperoleh bahwa sikap siswa bersikap positif. Hal ini ditunjukan dengan total skor 2111,04 berada pada rentang $2020 \leq \mathrm{s}<2640$ dengan interpretasi baik. Disajikan pula data dalam bentuk presentase, setelah dilakukan perhitungan mengenai skala sikap setiap individu kelas Discovery Learning sebagai berikut:

Tabel 4. Interpretasi Skala Sikap Setiap Individu Discovery Learning

\begin{tabular}{cccc}
\hline Nomor & Interpretasi & $\begin{array}{c}\text { Banyak } \\
\text { Siswa }\end{array}$ & $\begin{array}{c}\text { Persentase } \\
\mathbf{( \% )}\end{array}$ \\
\hline 1 & Sangat Jelek & 0 & 0 \\
\hline 2 & Jelek & 4 & 13,33 \\
\hline 3 & Baik & 16 & 53,34 \\
\hline 4 & Sangat Baik & 10 & 33,33 \\
\hline Jumlah & & 30 & 100 \\
\hline
\end{tabular}

Jadi, dapat disimpulkan bahwa interpretasi skala sikap siswa tiap individu terhadap pembelajaran matematika dengan menggunakan model pembelajaran Discovery Learning berinterpretasi baik.

Hasil dari penelitian ini mendukung hasil dari penelitian Miftah (2015) yang menyatakan bahwa kemampuan komunikasi matematis siswa dapat meningkat dengan menggunakan pembelajaran Model Eliciting Activities. Selain itu, hasil dari penelitian ini pun sejalan dengan temuan Haryati (2017) yang menyatakan bahwa kemampuan komunikasi matematis siswa dapat meningkat dengan menggunakan pembelajaran Discovery Learning. Sejauh dari yang peneliti baca, tidak ada yang meneliti tentang kemampuan komunikasi matematis dengan menggunakan keterlibatan antara dua variabel bebas yang peneliti lakukan, sehingga hal ini merupakan kebaruan dari penelitian ini.

\section{PENUTUP}

Berdasarkan hasil penelitian di lapangan dan kesimpulan mengenai pembelajaran matematika dengan menggunakan pembelajaran Model Eliciting Activities dan pembelajaran model Discovery Learning maka dapat diajukan beberapa saran bahwa pembelajaran Model Eliciting Activities dan Discovery Learning dapat meningkatkan kemampuan komunikasi matematis siswa, tetapi dilihat dari hasil pencapaian KKM tiap sisa, belum menunjukkan hasil yang optimal. Meskipun demikian secara umum kedua model tersebut dapat memberikan pengaruh positif terhadap matematika. 
Sehingga penulis menyaranan pengajar untuk menggunakan pemebelajaran Model Eliciting Activities dan Discovery Learning sebagai salah satu alternatif dalam memilih pembelajaran di kelas.

Bagi guru disarankan untuk lebih selektif dalam menentukan model pembelajaran yang akan digunakan agar sesuai dengan materi yang akan disampaikan sehingga mampu menciptakan suasana belajar yang menyenangkan dan tidak membosankan, serta pembelajaran menggunakan Model Eliciting Activities dan Discovery Learning dapat dijadikan salah satu alternatif untuk digunakan dalam pembelajaran matematika. Bagi siswa disarankan agar lebih banyak berlatih dengan mengerjakan soal-soal yang bervariasi dan berperan aktif dalam proses pembelajaran sehingga dapat meningkatkan kemampuan kognitifnya. Bagi pihak sekolah disarankan untuk lebih meningkatkan penyediaan sarana yang dapat menunjang terhadap proses belajar dan pembelajaran. Hasil penelitian ini hanya berlaku untuk siswa kelas X SMA Negeri 15 Garut tahun ajaran 2017-2018. Untuk penelitian yang lebih umum diperlukan penlitian lebih lanjut. Oleh karena itu, bagi peneliti selanjutnya yang menggunakan pembelajaran Model Eliciting Activities dan Discovery Learning ini bisa digunakan untuk ruang lingkup dan populasi yang lebih luas dengan pokok bahasan dan kemampuan matematis yang berbeda.

\section{DAFTAR PUSTAKA}

Afriansyah, E. A. (2016). Investigasi Kemampuan Problem Solving Dan Problem Posing Matematis Mahasiswa Via Pendekatan Realistic. Mosharafa: Jumal Pendidikan Matematika, 5(3), 269-280. Retrieved from http://emosharafa.org/index.php/mosharafa/article/view/mv5n3_9/161

Afriansyah, E. A. (2017). Desain Lintasan Pembelajaran Pecahan Melalui Pendekatan Realistic Mathematics Education. Mosharafa: Jurnal Pendidikan Matematika, 6(3), 463-474. Retrieved from http://e-mosharafa.org/index.php/mosharafa/article/view/mv6n3_15/137

Arifudin, M., Wilujeng, H., \& Utomo, R. B. (2016). Pengaruh Metode Discovery Learning Pada Materi Trigonometri Terhadap Kemampuan Penalaran Adaptif Siswa SMA. Kalamatika: Jurnal Pendidikan Matematika, 1(2). 129-140.

Burais, L., Ikhsan, M., \& Duskri, M. (2016). Peningkatan Kemampuan Penalaran Matematis Siswa melalui Model Discovery Learning. Jurnal Didaktik. Matematik, 3(1) 77-86.

Heryani, Y., \& Lesmana, D. (2017). Penggunaan Model Discovery Learning Terhadap Peningkatan Kemampuan Koneksi dan Komunikasi Matematik, Jurnal Raden Intan, 8(1), 4352.

Miftah, R. (2015). Pengaruh Pendekatan Model-Eliciting Activities (Meas) Terhadap Kemampuan Komunikasi Matematis Mahasiswa Program Dual Mode System (Dms). Matematika, 5(1), 2 3.

Nurdiansyah, B. (2008). Penggunaan Metode Penemuan untuk Meningkatkan Kemampuan Penalaran Induktif Siswa. [serial online]. http://newsmath. wordpress.com/2008/06/15/proposal-ptk.htm[25-09-2009]

Permana, Y. (2010). Mengembangkan Kemampuan Pemahaman, Komunikasi, dan Disposisi Matematis Siswa Sekolah Menengah Atas Melalui Model Eliciting Activities. Disertasi PPs UPI, Bandung. 
Rahman, R. \& Maarif, S. (2014). Pengaruh Penggunaan Metode Discovery Terhadap Kemampuan Analogi Matematis Siswa Smk Al-Ikhsan Pamarican Kabupaten Ciamis Jawa Barat. Infinity Journal, 3(1), 33-58.

Ruseffendi, E. T. (2005). Dasar-dasar Penelitian Pendidikan dan Bidang Non Eksakta Lainnya. Bandung: Tarsito.

Ruseffendi. E. T. (2006). Pengantar Kepada Membantu Guru Mengembangkan Kompetensinya dalan Pengajaran Matematika untuk. Meningkatkan CBSA. Bandung: Tarisito.

Santi, N. L. (2012). Pengaruh Model Eliciting Activities Terhadap Hasil Belajar Matematika Pada Siswa Kelas V di SDN 1 Baturiti. Singaraja: Universitas Pendidikan Ganesha.

Suherman, E. dkk. (2001). Strategi Pembelajaran Matematika Kontemporer. Bandung: Jica.

Sumarmo, U. \& Hendriana, H. (2014). Penilaian Pembelajaran Matematika. Bandung: Refika Aditama.

Wijayanti, S. P. (2013). Pengaruh Pendekatan MEAs terhadap Kemampuan Pemecahan Masalah, Komunikasi Matematis, dan Kepercayaan Diri Siswa. Pythagoras: Jurnal Matematika dan Pendidikan Matematika, 8(2), 181-192. 